\title{
Reply to the comments by Rabindra Nath Hota on 'Volatile displacement of Meghalaya coals - A pointer to explore low sulphur coals'
}

\author{
P BEHERA \\ P.G. Department of Geology, Utkal University, Vani Vihar, Bhubaneswar 751004 , India. \\ e-mail: pn_behera@indiatimes.com
}

\section{Reply 1}

It is written in the formula and the letters $\mathrm{H}$ and $\mathrm{C}$ need to be explained below. It was also suggested by esteemed reviewers.

\section{Reply 2}

The volatile displacement means the difference between calculated and experimental volatile matter, the formula in practice is written as (-). In most text books this is followed (Ref. Van Krevelen, p. 22; Chandra and Singh 2000, p. 110).

\section{Reply 3}

Seyler prepared a chart taking carbon and hydrogen as rectilinear co-ordinates. It has been drawn in such a manner that one unit of carbon corresponds to five units of hydrogen and carbon units are shown to decrease from 100\% carbon. This chart includes all varieties of coal composition and was used for coal classification. Volatile matter and calorific values are also taken into account by two more axes perpendicular to each other but inclined at an angle $60^{\circ}$. A narrow band is drawn (three bold lines) between carbon limits $70-97 \%$ and hydrogen limits $2.0-5.8 \%$, which is known as Seyler's band which includes the composition of all bright normal coals. This is the band within Seyler's Coal chart No. 47B (Ref. Wilfrid Francis, p. 299; Chandra et al 2000, p. 109).

\section{Reply 4}

I agree that the formula proposed by Dr. Hota is the correct typed formula and in my case it was a typing error. This thing I had replied earlier.

\section{Reply 5}

The best fit lines are drawn but it has come out faint in the print (figure $3 \mathrm{~b}, \mathrm{c}, \mathrm{h}$ ), but it is there in my original copy.

\section{Reply 6}

It is a typographical mistake. It should be read as 'upward decrease in the middle seam' and again 'increase in the top seams'.

\section{Reply 7}

This is also a typographical error. In table 3 , the values are there. It ranges from 0.08 to 0.73 .

\section{Reply 8}

The published data of Chandra et al's paper (1983) has been used. To match with eight values of table 3 , the values of table 2 have been converted to eight values by taking the average, for example, Nangalbiba having seam I and seam II. Its average value is taken. Similarly for Laitryngew and Bapung. I do not think it as wrong. Moreover, in proximate analysis, ash, moisture and volatile matter being different, the carbon in ultimate analysis may be the same.

Keywords. Volatile displacement; coal; Meghalaya. 
Table 1. Revised, corresponding to table 3 of original paper.

\begin{tabular}{lcccrrrrr}
\hline Coalfield & $\mathrm{Ps}$ & $\mathrm{Ss}$ & $\mathrm{Os}$ & $\mathrm{O}_{2}$ & $\mathrm{O}_{2}+\mathrm{Ss}$ & $\mathrm{O}_{2}+\mathrm{Ps}$ & $\mathrm{O}_{2}+\mathrm{Oss}$ & $\mathrm{Ts}$ \\
\hline Nangalbibra & 0.05 & 0.32 & 2.18 & 12.90 & 13.22 & 12.95 & 15.08 & 2.55 \\
Siju & 0.26 & 0.18 & 1.55 & 13.90 & 14.08 & 14.16 & 15.45 & 1.99 \\
Langrin & 0.58 & 0.21 & 2.46 & 13.05 & 13.26 & 13.63 & 13.51 & 3.25 \\
Mawsynram & 0.37 & 0.66 & 1.43 & 9.50 & 10.16 & 9.87 & 10.93 & 2.46 \\
Laitryngew & 0.06 & 0.73 & 2.63 & 8.70 & 9.43 & 9.25 & 11.33 & 3.22 \\
Ishamati & 0.85 & 0.03 & 2.74 & 9.90 & 9.93 & 10.75 & 12.64 & 3.62 \\
Bapung & 1.06 & 0.67 & 5.10 & 10.45 & 11.12 & 11.51 & 15.55 & 6.83 \\
Lumshnong & 0.82 & 0.08 & 4.33 & 6.38 & 6.46 & 7.2 & 10.71 & 5.23 \\
\hline
\end{tabular}

Table 2. Revised, corresponding to table 4 of original paper.

\begin{tabular}{|c|c|c|c|c|c|c|}
\hline $\begin{array}{l}\text { Fig. } \\
\text { no. }\end{array}$ & Parameters & $\begin{array}{l}\text { Correlation } \\
\text { coefficient }(r)\end{array}$ & $r^{2}$ & $\begin{array}{c}t \\
\text { (calculated) }\end{array}$ & $\begin{array}{c}t \\
\text { (critical) }\end{array}$ & Inference \\
\hline $3(\mathrm{a})$ & $\mathrm{C}$ and $\delta v$ & 0.6154 & 0.3788 & 2.342 & 2.2622 & Significant \\
\hline $3(\mathrm{~b})$ & $\mathrm{H}$ and $\delta v$ & 0.1029 & 0.0106 & 0.3105 & 2.2622 & Not significant \\
\hline $3(\mathrm{c})$ & $\mathrm{O}_{2}$ and $\delta v$ & 0.7755 & 0.6015 & 3.685 & 2.2622 & Significant \\
\hline $3(\mathrm{~d})$ & $\mathrm{O}_{2}+\mathrm{Ss}$ and $\delta v$ & 0.785 & 0.6188 & 3.105 & 2.446 & Significant \\
\hline $3(\mathrm{e})$ & $\mathrm{O}_{2}+\mathrm{Ps}$ and $\delta v$ & 0.703 & 0.4952 & 2.424 & $\begin{array}{l}2.446 \\
1.9432\end{array}$ & Significant at $10 \%$ level \\
\hline $3(\mathrm{f})$ & $\mathrm{O}_{2}+\mathrm{Os}$ and $\delta v$ & 0.519 & 0.2697 & 1.488 & 2.446 & Not significant \\
\hline $3(\mathrm{~g})$ & $\mathrm{M}$ and $\delta v$ & 0.483 & 0.234 & 1.656 & 2.2622 & Not significant \\
\hline $3(\mathrm{~h})$ & Ts and $\delta v$ & 0.758 & 0.5751 & 2.851 & 2.446 & Significant \\
\hline
\end{tabular}

\section{Reply 9}

Same as above.

\section{Reply 10}

The typographical errors which were there in table 3 , have now been correctly reflected as revised table 1 (above).

\section{Reply 11}

I agree, the figures should have been numbered as $3(\mathrm{a})$ to $3(\mathrm{~h})$.

\section{Reply 12}

From the revised calculation it can now be seen that oxygen $v s$. $\delta v$ relation is significant and the statement volatile displacement increase with increase of oxygen is also correct.

\section{Reply 13}

The revised table 2 (above) corresponding to table 4 explains all the points raised by Dr Hota.

\section{Reply 14}

I agree that marine regression is a spatial phenomenon, but the trend surface analysis of coal parameters cannot take care of the replacement phenomenon. The abnormality of coal related to $\delta v$ explains the things. Yes, if the number of samples were more, the conclusions would have been stronger.

\section{Reply 15}

The revised table put up after recalculation and cross checking (revised table 2 corresponding to table 4) vindicates the approach and nomenclature of the title of the paper.

\section{References}

Chandra D, Mazumdar K and Basumallik S 1983 Distribution of sulphur in tertiary coals of Meghalaya; Int. J. Coal Geol. 3 63-75.

Chandra D, Singh R M and Singh M P 2000 Text Book of Coal; Tara Book Agency, Kamachha, Varanasi.

Van Krevelen, Coal in its various aspects - Part I.

Wilfrid Francis 1961 Coal, its formation and composition; 2nd edn. (London: Edward Arnold Publication). 